\title{
Morfometri, Pemijahan, dan Indeks Kematangan Gonad Teripang Komersial di Perairan Pulau Nyamuk, Karimunjawa
}

\author{
Mustagfirin*, Diah Permata Wijayanti, Subagiyo \\ Departemen IImu Kelautan, Fakultas Perikanan dan IImu Kelautan, Universitas Diponegoro \\ JI. Prof. H. Soedarto, S.H., Tembalang, Semarang 50275 Indonesia \\ Email : mustagfirin150895@gmail.com
}

\section{Abstract \\ Morphometric, Spawning and Gonad Maturity Index of Commercial Sea Cucumbers in Nyamuk Island, Karimunjawa}

Sea cucumbers are marine organisms that live in coral reef ecosystem habitats and their associations. Sea cucumbers have been used by communities as food, cosmetics and traditional medicine in various countries. The benefits and high economic value of sea cucumbers make fisheries activities occured massively and continuously. Sea cucumbers were large commodity from Indonesian waters. However, until now it has not received proportional attention. The lack of information on morphometry, spawning in various regions has made the commodity of sea cucumbers decreased. This research was conducted to determine the character of commercial sea cucumber commodities in Pulau Nyamuk, to the occurrence of spawning based on the moon phase. This research was conducted in September - November 2020. This research method uses an analysis approach of gonadal maturity index in determining the spawning of sea cucumbers. The results showed that commercial sea cucumbers in Pulau Nyamuk were Pisang (Holothuria sp.) and Gamat (Stichopus sp.) Sea cucumber. This sea cucumber weighs 300-690 grams wet. Sea Cucumbers, Pisang and Gamat tend to have high IKG values in the new moon phase with IKG index values $>10 \%$.

Keywords : Morphometric, Spawning, Gonad Maturity Indeks, Commercial Sea Cucumber

\begin{abstract}
Abstrak
Teripang merupakan organisme laut yang hidup pada habitat ekosistem terumbu karang dan asosiasinya. Teripang telah dimanfaatkan oleh masyarakat di sekitar pantai sebagai bahan makanan, kosmetik serta obat tradisional di berbagai negara. Manfaat serta nilai ekonomi teripang yang tinggi membuat aktivitas pemburuan terjadi secara masif dan terus menerus. Teripang juga merupakan komoditas besar yang berasal dari Perairan Indonesia. Namun hingga saat ini belum memperoleh perhatian yang proporsional. Minimnya informasi mengenai morfometri, pemijahan di berbagai daerah membuat komoditas teripang turun secara drastis. Penelitian ini dilakukan untuk mengetahui karakter komoditas teripang komersial di Pulau Nyamuk, hingga terjadinya pemijahan berdasarkan fase bulan. Penelitian ini bulan September - November 2020 di Perairan Pulau Nyamuk Kecamatan Karimunjawa, Kabupaten Jepara. Metode penelitian ini menggunakan pendekatan analisis indeks kematangan gonad dalam menentukan pemijahan teripang. Hasil penelitian menunjukkan bahwa teripang komersial di Pulau Nyamuk adalah jenis teripang Pisang (Holothuria sp.) dan Gamat (Stichopus sp.). Teripang ini mempunyai berat 300-690 gram basah. Teripang Pisang dan Gamat cenderung mempunyai nilai IKG yang tinggi pada bulan baru dengan nilai indeks IKG $>10 \%$.
\end{abstract}

Kata kunci : Morfometri, Pemijahan, Indeks Kematangan Gonad, Teripang Komersial

\section{PENDAHULUAN}

Teripang merupakan organisme laut yang diketahui juga sebagai "trepang"
(Malaysia), "bêche de-mer" (French), "namako" (Japan), "plingkao" (Thailand), "haishen" (China), dan di pasar internasional disebut dengan "sandfish" (Pangkey et al., 
2012), sedangkan di Indonesia biota ini lebih sering disebut dengan nama "teripang", "gamat", atau "gamet" (Hartati et al., 2009).Teripang merupakan biota laut yang masuk dalam Filum Echinodermata (Suryaningrum, 2008), dan mempunyai bentuk tubuh silindris berukuran sekitar $10-30 \mathrm{~cm}$, memanjang dari ujung mulut ke arah anus (orally-aborally) (Darsono, 2007), berotot dengan kulit yang halus dan berbintil (Elfidasari et al., 2012). Holothuridea memiliki 3 famili yaitu Holothuriidae (Genus Actinopyga dan Holothuria), Stichopodidae (Genus Stichopus), dan Synaptidae (Genus Synapta) (Hadi et al., 2011). Teripang hidup pada habitat ekosistem terumbu karang dan asosiasinya (Sulardiono dan Hendrarto, 2014). Ekosistem terumbu karang dan ekosistem lamun yang mempunyai kelimpahan nutrien pada sedimennya merupakan habitat potensial bagi teripang (James, 1996) dan (Setyastuti, 2014). Karakteristik lain dari teripang adalah hidup sebagai hewan nokturnal, yakni teripang akan keluar dari substrat pada malam hari dan saat air surut (Sulardiono dan Hendrarto, 2014).

Di Indonesia, teripang telah dimanfaatkan oleh masyarakat di sekitar pantai sebagai bahan makanan (Martoyo et al., 2006). Bangsa Cina, sejak Dinasti Ming, telah menjadikan teripang sebagai bahan baku dasar obat tradisional (Nurwidodo et al., 2018). Wibowo et al., (1997) menyatakan bahwa teripang mengandung senyawa antioksidan yang berfungsi mengurangi kerusakan sel jaringan tubuh. Dakrory et al., (2015) berpendapat bahwa teripang mempunyai manfaat sebagai anti kanker payudara yang didapat dari ekstraknya.

Sulardiono (2016) mengatakan bahwa Potensi biomassa populasi seluruh spesies teripang yang dimanfaatkan di Perairan Karimunjawa sebesar 44.641 .789 individu/tahun dengan nilai potensi lestari (MSY) sebesar 24.590.814 individu/tahun, dengan jumlah pengambilan yang diperbolehkan sebesar 20.277.981 individu/tahun. Lebih lanjut, data penangkapan teripang di Pulau Nyamuk, Karimunjawa menyumbang $1.478 \mathrm{Kg}$ atau 44.340 individu. Sektor perikanan, komoditas teripang belum memperoleh perhatian yang proporsional dari sektor perikanan Indonesia (Husain et al. 2017). Minimnya pengetahuan masyarakat mengenai kondisi stok teripang di alam dan upaya ekploitasi secara berlebihan menjadi salah satu faktor turunnya populasi teripang di alam (Hasan 2019).

Pulau Nyamuk merupakan salah satu kepulauan di wilayah administrasi Karimunjawa yang mempunyai komoditas teripang komersial (Mustagfirin dan Hartati, 2016), dengan aktivitas eksploitasi teripang (Mustagfirin et al., 2021). Kondisi stok teripang yang belum diketahui di alam dapat memicu habisnya populasi teripang dalam waktu dekat. Muhammad Fagih (Komunikasi Pribadi, 2019) menyatakan bahwa di Pulau Nyamuk penangkapan teripang dilakukan setiap hari. Penangkapan teripang yang dilakukan tiap hari dapat menganggu proses dari spawning atau pemijahan. Hal tersebut dapat diasumsikan bahwa aktivitas penangkapan yang tidak sesuai dapat menganggu stok dan waktu pemijahan teripang di alam.

Banyak faktor lingkungan yang diduga berpengaruh pada aktivitas reproduksi teripang (Hartati dan Yanti 2006), dalam penelitiannya pada spesies $H$. vagabunda dilaporkan memijah pada saat bulan baru di Perairan Jepara, Jawa Tengah. Penelitian lain H. scabra diamati pada saat bulan purnama di Langgur, Maluku Tenggara juga mengalami pemijahan (Rahantoknam, 2017). Berbagai hal diatas, maka perlunya informasi mengenai informasi siklus bulan yang berkaitan dengan pemijahan teripang di alam. Hal tersebut mendasari mengenai pentingnya penelitian ini dilakukan untuk mengetahui karakter morfometri serta waktu pemijahan teripang di Pulau Nyamuk Karimunjawa. Hal tersebut dilakukan melalui pendekatan dengan mengamati indeks kematangan gonad (IKG) teripang selama 2 kali siklus bulan. Selain itu, pengamatan ini bertujuan untuk pementukan PERDES (Peraturan Desa) Pulau Nyamuk mengenai penangkapan yang ideal untuk mengatur kelestarian sumber daya teripang.

\section{MATERI DAN METODE}

Penelitian dilaksanakan pada bulan September - November 2020 di Perairan Pulau Nyamuk Kecamatan Karimunjawa, 
Kabupaten Jepara, Provinsi Jawa Tengah. Sampel penelitian merupakan teripang jenis komersial yang ada di Pulau Nyamuk. Jumlah teripang yang diukur sebanyak 500 ekor yang terdiri dari 2 jenis teripang komersial di Pulau Nyamuk yaitu teripang Pisang dan Gamat (Holothuria sp. dan Stichopus sp.). Penelitian serupa yang dilakukan di Pulau Nyamuk oleh penulis di publikasikan di tempat berbeda, sehingga terjadi kesamaan topik namun berbeda spesies.

Pengukuran morfometri dilakukan untuk mengetahui panjang dan berat teripang serta variabel lain seperti berat air, berat basah teripang, berat pohon respirasi serta berat feses teripang, yang selanjutnya dilakukan kluster kelas atau pengelompokan teripang berdasarkan jenis dan ukurannya. Jumlah teripang yang didata 250 ekor selama penelitian dengan minimal berat basah 200 gram.

Pengukuran panjang berat basah teripang dilakukan di lokasi pengepul teripang pada pagi hari, dimana pada pagi hari teripang dari nelayan dijual di lokasi pengepul untuk dikeringkan. Teripang yang telah diberi label diletakkan di atas meja kerja berskala untuk diukur panjangnya dengan mistar $(0,1$ $\mathrm{mm})$, berat diukur dengan timbangan digital $(0,1 \mathrm{~g})$. Mengingat teripang bersifat elastik, sebelum diukur teripang didiamkan terlebih dahulu sampai teripang berhenti mengeluarkan air (Purcell et al., 2009), meskipun terdapat metode untuk membuat pingsan teripang, namun peneliti mempunyai keterbatasan dalam menyediakan komponen tersebut. Setelah pengukuran, teripang yang belum diketahui jenisnya diberi larutan alkohol $70 \%$ untuk proses pengawetan sampel, kemudian teripang diidentifikasi berdasarkan referensi panduan yaitu Brueggeman (1998); Kerr et al. (2006); Purcell et al. (2012).

Pendataan tingkat kematangan gonad secara kuantitatif mengikuti model (Hoaerou dan Conand, 2001). Pendataan Tingkat Kematangan Gonad (TKG) ini dilakukan untuk menentukan kondisi teripang dalam mencapai tahap atau masa reproduksi secara deskriptif. Adapun metode pembanding yang digunakan untuk pengamatan morfologi pencernaan dan kondisi teripang berdasarkan Yu dan Jo (1984).

Pengamatan Indeks Kematangan Gonad (IKG) di sesuaikan dengan fase bulan menggunakan referensi Aplikasi NASA Moonphase 3.3 dan pengamatan langsung di lapangan selama September-November 2020. Adapun fase tersebut adalah Kuartal Pertama, Cembung Awal, Bulan Purnama, Cembung Akhir, Kuartal Ketiga, Bulan Sabit Akhir, Bulan Baru, Bulan Sabit Awal.

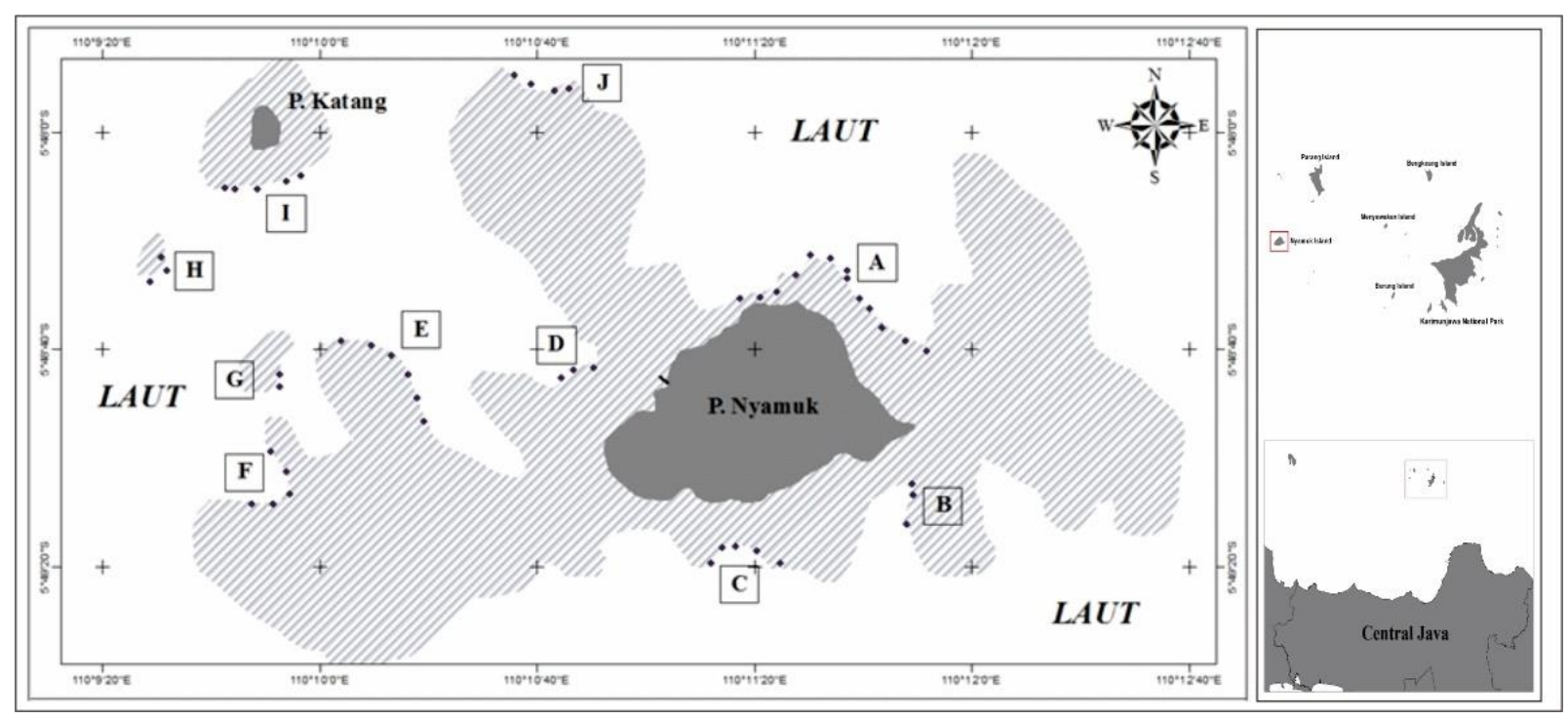

Gambar 1. Lokasi Pengambilan Sampel di Pulau Nyamuk 
Indeks Kematangan Gonad (IKG) ditentukan dengan cara berat tegumen dan berat gonad sampel teripang ditimbang menggunakan timbangan Neraca. Menurut Tuwo dan Conand (1992), rumus untuk menghitung IKG adalah :

$$
\begin{gathered}
\text { IKG }= \\
\frac{\text { Berat Gonad }}{\text { Berat tegumen (berat tubuh tanpa organ dalam) }} \times 100 \%
\end{gathered}
$$

Kegunaan nilai IKG adalah untuk mengetahui fase reproduksi gonad, sehingga waktu pemijahan dapat diketahui (Effendie, 1997). Menurut Mustofa (2014), tahap perkembangan gonad teripang genus Holothuria dibedakan menjadi lima fase reproduksi yaitu: Fase pengosongan = bobot gonad sekitar 0,6 gram, IKG kurang dari $1 \%$; Fase perkembangan : bobot gonad berkisar antar 0,2 - 2,0 gram, IKG kurang dari 1\%; Fase pengaktifan I = bobot gonad $2-5$ gram, warna kuning atau orange, IKG $1-3 \%$; Fase pengaktifan $\|=$ bobot gonad $3-13$ gram, IKG 7\%; Fase pematangan = bobot gonad 10 gram, IKG 10\%; Fase pemijahan = bobot gonad lebih dari 10 gram, IKG lebih dari $10 \%$.

\section{HASIL DAN PEMBAHASAN}

Hasil analisa karakter morfometri teripang Pisang Jantan (Gambar 2.A) selama penelitian, didapatkan hasil teripang dengan rata-rata panjang $23,3 \mathrm{~cm}$, lebar $4,53 \mathrm{~cm}$, dan berat basah 294,7 gram. Maka berat rata-rata tegumen sebesar 206,6 gram (70\%), Pohon respirasi $7 \%(20,04$ gram), cuvierian tubula $5 \%$ $(13,49$ gram), dan berat air dan feses $19 \%$ (54,57 gram). Sedangkan hasil analisa karakter morfometri teripang Pisang betina (Gambar 2.B) selama penelitian, didapatkan hasil teripang dengan rata-rata panjang $23,68 \mathrm{~cm}$, lebar $4,65 \mathrm{~cm}$, dan berat basah 310,7 gram. Maka berat rata-rata tegumen sebesar 213,3 gram (69\%), Pohon respirasi $7 \%(21,24$ gram), cuvierian tubula $4 \%$ (12,92 gram), dan berat air dan feses $20 \%$ (63,13 gram). Hasil pengukuran karakter morfometri teripang selama penelitian disajikan pada Tabel 1.

Tabel 1. Hasil Pengukuran Karakter Morfometri Teripang

\begin{tabular}{lcccc}
\hline \multirow{2}{*}{ Karakter } & \multicolumn{2}{c}{ Pisang } & \multicolumn{2}{c}{ Gamet } \\
\cline { 2 - 5 } Morfometri & \multicolumn{2}{c}{ Holothuria sp. } & \multicolumn{2}{c}{ Stichopus sp. } \\
\hline Jenis Kelamin & Jantan \pm SD & Betina \pm SD & Jantan \pm SD & Betina $\pm S D$ \\
\hline Panjang (cm) & $23,30 \pm 5,75$ & $23,68 \pm 5,75$ & $28,59 \pm 5,73$ & 5,73 \\
Lebar (cm) & $4,53 \pm 3,04$ & $4,65 \pm 3,05$ & $8,13 \pm 3,05$ & $7,97 \pm 3,04$ \\
Berat Basah(g) & $294,73 \pm 229,46$ & $310,65 \pm 229,53$ & $661,57 \pm 229,35$ & $690,93 \pm 230,20$ \\
Air dan Feses (g) & $54,57 \pm 93,63$ & $63,13 \pm 93,70$ & $200,69 \pm 93,84$ & $229,59 \pm 94,47$ \\
Berat Tegumen (g) & $206,63 \pm 160,76$ & $213,31 \pm 160,88$ & $359,53 \pm 160,93$ & $354,10 \pm 160,87$ \\
Berat PR (g) & $20,04 \pm 41,89$ & $21,24 \pm 41,91$ & $101,34 \pm 41,84$ & $107,24 \pm 42,00$ \\
Berat CV (g) & $13,49 \pm 16,61$ & $12,92 \pm 16,53$ & - & - \\
Jumlah Sampel (ekor) & 92 & 158 & 107 & 143 \\
\hline Sex Ratio & 1 & 1,7 & 1 & 1,3 \\
\hline
\end{tabular}

*SD : Standar Deviasi (+-)

(A)

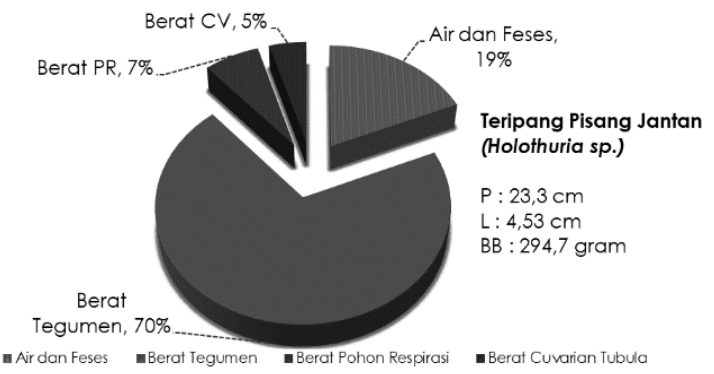

(B)

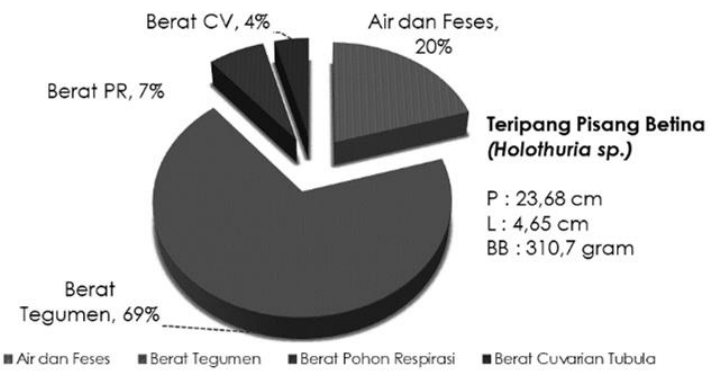

Gambar 2. Karakter Morfometri Teripang Pisang (A : Jantan, B : Betina) 
Hasil analisa karakter morfometri teripang Gamet Jantan (Gambar 3.A) selama penelitian, didapatkan hasil teripang dengan rata-rata panjang $28,59 \mathrm{~cm}$, lebar $8,13 \mathrm{~cm}$, dan berat basah 661,6 gram. Maka berat ratarata tegumen sebesar 359,5 gram (55\%), pohon respirasi $15 \%$ (101,3 gram) dan berat air dan feses 30\% (200,7 gram). Sedangkan hasil analisa karakter morfometri teripang Gamet betina (Gambar 18) selama penelitian, didapatkan hasil teripang dengan rata-rata panjang $28,82 \mathrm{~cm}$, lebar $7,97 \mathrm{~cm}$, dan berat basah 690,9 gram. Maka berat rata-rata tegumen sebesar 354,1 gram (51\%), pohon respirasi $16 \%(107,2$ gram) dan berat air dan feses 33\% (229,6 gram).

\section{Pembahasan Karakter Morfometri Teripang}

Teripang yang dijadikan obyek penelitian adalah teripang komersial di Perairan Pulau Nyamuk, Karimunjawa. Teripang pertama yaitu jenis Pisang atau (Holothuria sp.). Teripang ini mempunyai karakteristik panjang maksimal 23,30-23,68 $\mathrm{cm}$, lebar maksimal 4,53-4,65 cm dengan berat maksimal mencapai 310,65 gram. Berat teripang tersebut mirip dengan penelitian (Navaro et al., 2021) pada spesies Holothuria sanctori seberat 200 gram. Hal tersebut disimpulkan bahwa ukuran berat teripang di lokasi penelitian mirip dengan berat teripang di Spanyol. Sedangkan parameter panjang teripang mempunyai kisaran nilai yang berbeda dengan penelitian Kithakeni and Ndaro (2002), dimana pada spesies Holothruia scabra mempunyai panjang $17 \mathrm{~cm}$. Hal tersebut berbeda dikarenakan metode pengukuran dan kondisi teripang di setiap lokasi penelitian berbeda. Sifat teripang yang lunak serta mudah untuk berubah bentuk (Nontji, 2002), menjadi alasan bahwa terdapat perbedaan hasil pengukuran. Teripang jenis ini ditemukan pada kedalaman 5-10 meter dengan substrat (rubbel) di Perairan Pulau Nyamuk. Hal tersebut sesuai dengan pernyataan Sulardiono dan Hendrarto (2014), bahwa teripang hidup berdampingan dengan ekosistem terumbu karang. Teripang Pisang merupakan teripang yang masuk kedalam kelompok Fissiparous Holothurians dimana mempunyai Cuvierian Tubules sebanyak 4-5\% dari total tegumen (berat tubuh tanpa organ) atau dengan berat $12,92-13,49$ gram.

Teripang kedua yang dijadikan obyek penelitian adalah jenis Teripang Gamet (Stichopus sp.), dimana teripang ini merupakan komoditas unggulan dari Pulau Nyamuk, Karimunjawa (Musyafak, Komunikasi Pribadi 2020). Teripang Gamet mempunyai panjang maksimal mencapai $28,59-28,82 \mathrm{~cm}$, lebar maksimal mencapai 7,97-8,13 cm, dengan berat maksimal mencapai 690,93 gram. Jenis teripang Gamet mempunyai ukuran mencapai $28,6 \mathrm{~cm}$ menurut Sulardiono (2011) di Kecamatan Karimunjawa. Hal tersebut menandakan bahwa teripang di Pulau Nyamuk dan Karimunjawa mempunyai kemiripan panjang. Sedangkan parameter lain seperti lebar dan berat belum bisa dibandingkan, karenan minimnya penelitian yang dilakukan serta data yang tidak selalu ada (Kohler et al. 2009). Teripang Gamet di temukan pada kedalaman 5-25 meter, hal tersebut sesuai dengan referensi Yusro (2001) bahwa teripang jenis ini ditemukan di perairan berkisar 5-15 m. Teripang Gamet tidak termasuk jenis teripang yang mempunyai Cuvierian Tubules, hal ini ditandai dengan tidak ditemukanya jaring putih khas dan lengket yang biasanya dimiliki oleh teripang yang mempunyai Cuvierian Tubules.
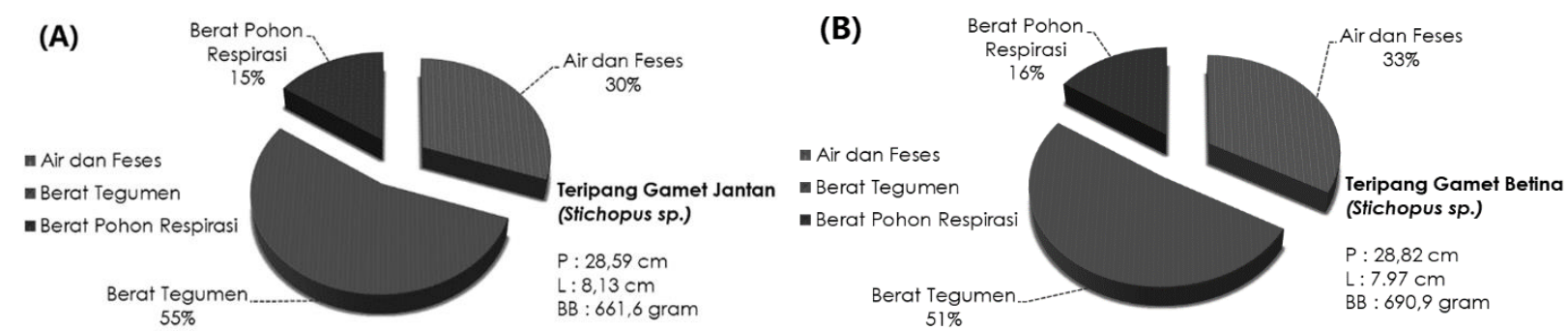

Gambar 3. Karakter Morfometri Teripang Gamet (A : Jantan, B : Betina) 


\section{Hasil Tingkat Kematangan Gonad}

Pada saat penelitian total Teripang Pisang berjumlah 250 individu, dimana terbagi menjadi 92 teripang jantan, dan 158 teripang betina. Sedangkan Teripang Gamet berjumlah 250 individu, dimana terbagi menjadi 107 teripang jantan, dan 143 teripang betina. Adapun hasil prosentase tingkat kematangan gonad teripang disajikan pada Gambar 4.

Hasil penelitian Komposisi TKG pada teripang jantan terbagi menjadi TKG I sebanyak (27 individu), TKG II (21 individu), TKG III (17 individu), TKG IV (13 individu), dan TKG V sebanyak (14 individu), dimana pada saat penelitian didominasi oleh TKG I. Sedangkan komposisi TKG pada teripang Pisang betina mempunyai pembagian sebagai berikut yaitu TKG I sebanyakr (35 individu), TKG ॥ (39 individu), TKG III (32 individu), TKG IV (31 individu), dan TKG $\vee$ sebanyak 13,29 \% (21 individu).

Pada komposisi teripang Gamet jantan TKG I berjumlah (19 individu), TKG ॥ (23 individu), TKG III (27 individu), TKG IV (29 individu), dan TKG $\vee$ sebanyak (9 individu). Sedangkan Teripang Gamet betina Teripang gamet TKG I sebanyak (32 individu), TKG II (31 individu), TKG III (42 individu), TKG IV (28 individu), dan TKG V sebanyak (10 individu).

\section{Hasil Indeks Kematangan Gonad}

Hasil pengamatan IKG (indeks kematangan gonad) teripang periode pertama (Siklus 1) Jenis Pisang mempunyai hasil IKG tertinggi pada fase bulan baru (17 Okt) sebesar $13,04 \%$ dan terendah pada fase cembung awal (28 Sep) sebesar $0,16 \%$. Sedangkan Teripang Gamet mempunyai nilai IKG tertinggi pada fase bulan baru (17 OKt) dengan nilai $15,94 \%$, sedangkan terendah terjadi pada fase cembung awal (28 Sept) dengan nilai $0,01 \%$.

Hasil pengamatan IKG (indeks kematangan gonad) teripang periode kedua (Siklus 2) Jenis Pisang mempunyai hasil IKG tertinggi pada fase bulan baru (15 Nov) sebesar $18,77 \%$ dan terendah pada fase bulan purnama (31 $\mathrm{Okt}$ ) sebesar $0,51 \%$. Teripang Gamet mempunyai nilai IKG tertinggi pada fase bulan sabit akhir (11 Nov) dengan nilai $13,32 \%$, sedangkan terendah terjadi pada fase bulan sabit awal (18 Nov) dengan nilai $0,63 \%$. Hasil pengamatan indeks kematangan gonad teripang di Perairan Pulau Nyamuk disajikan pada Tabel 2.

Hasil Indeks Kematangan gonad didapatkan dari hasil pengamatan indeks kematangan gonad sebelumnya yang dikuantifikasi. Hasil pengamatan indeks kematangan gonad Teripang Pisang (Holothuria sp.) selama dua siklus bulanan, didapatkan

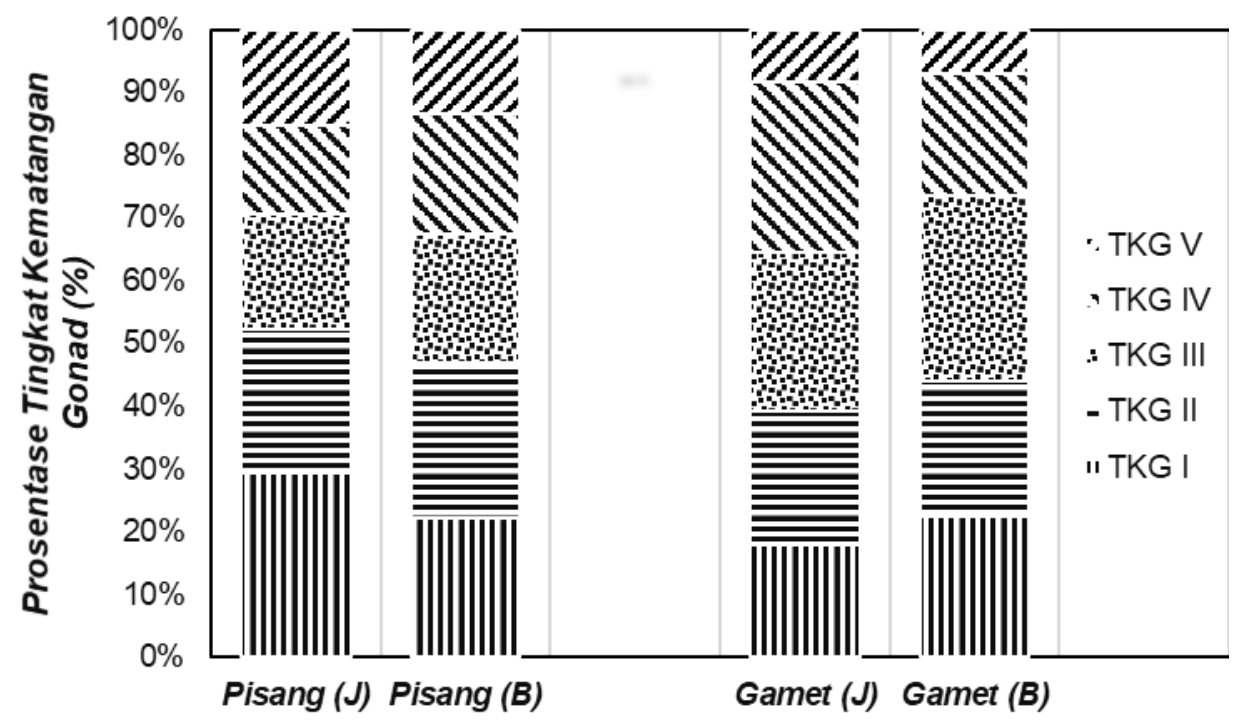

Gambar 3. Prosentase Tingkat Kematangan Gonad (TKG) Teripang Pisang dan Gamet (J : Jantan, B: Betina). 
Tabel 2. Hasil Pengukuran Indeks Kematangan Gonad Teripang

\begin{tabular}{|c|c|c|c|c|c|c|}
\hline \multirow[t]{2}{*}{ Fase Bulan } & \multirow{2}{*}{$\begin{array}{c}\text { Siklus } \\
\text { Bulan Ke }\end{array}$} & \multicolumn{2}{|c|}{ IKG (Teripang Pisang) } & \multirow{2}{*}{ Waktu } & \multicolumn{2}{|c|}{ (IKG)Teripang Gamet } \\
\hline & & Jantan & Betina & & Jantan & Betina \\
\hline Kuartal Pertama & 1 & 0,83 & 0,68 & $24 \mathrm{Sep}$ & 7,32 & 9,12 \\
\hline Cembung Awal & 1 & 0,16 & 0,64 & $28 \mathrm{Sep}$ & 0,01 & 1,77 \\
\hline Bulan Purnama & 1 & 1,06 & 2,44 & $2 \mathrm{Okt}$ & 0,72 & 1,36 \\
\hline Cembung Akhir & 1 & 7,82 & 6,46 & $6 \mathrm{Okt}$ & 7,21 & 5,01 \\
\hline Kuartal Ketiga & 1 & 8,62 & 5,15 & $10 \mathrm{Okt}$ & 7,91 & 9,12 \\
\hline Bulan Sabit Akhir & 1 & 10,32 & 11,15 & $13 \mathrm{Okt}$ & 15,33 & 10,88 \\
\hline Bulan Baru & 1 & 13,04 & 11,33 & 17 Okt & 15,22 & 15,94 \\
\hline Bulan Sabit Awal & 1 & 7,78 & 3,70 & $20 \mathrm{Okt}$ & 2,91 & 2,09 \\
\hline Kuartal Pertama & 2 & 3,34 & 3,22 & $23 \mathrm{Okt}$ & 0,81 & 1,32 \\
\hline Cembung Awal & 2 & 3,24 & 3,60 & 27 Okt & 1,13 & 1,29 \\
\hline Bulan Purnama & 2 & 1,39 & 0,51 & $31 \mathrm{Okt}$ & 3,09 & 1,09 \\
\hline Cembung Akhir & 2 & 0,00 & 6,13 & $5 \mathrm{Nov}$ & 4,36 & 5,35 \\
\hline Kuartal Ketiga & 2 & 9,37 & 0,00 & $8 \mathrm{Nov}$ & 4,35 & 6,13 \\
\hline Bulan Sabit Akhir & 2 & 10,33 & 8,18 & $11 \mathrm{Nov}$ & 13,20 & 13,32 \\
\hline Bulan Baru & 2 & 18,77 & 12,38 & $15 \mathrm{Nov}$ & 1,71 & 6,06 \\
\hline Bulan Sabit Awal & 2 & 3,00 & 4,07 & $18 \mathrm{Nov}$ & 1,86 & 0,68 \\
\hline
\end{tabular}

bahwa nilai indeks tertinggi terjadi pada fase Bulan Baru. Nilai IKG pada fase bulan tersebut sebesar (12,58-14,94\%). Mustofa (2014) mengatakan bahwa nilai IKG tersebut termasuk kedalam fase pemijahan yakni (>10\%). Nilai indeks terendah terjadi pada fase Cembung Awal dengan nilai IKG kurang dari (1\%) dan termasuk kedalam kategori fase pengosongan sesuai dengan referensi (Mustofa, 2014). Hal tersebut dapat disimpulkan bahwa Teripang Pisang memijah pada fase pada saat bulan baru. Hal tersebut sesuai dengan referensi Hartati dan Yanti, (2006) dimana pada teripang jenis $H$. vagabunda di Perairan Jepara, Jawa Tengah yang memijah pada bulan baru.

Pada saat penelitian, Teripang Pisang mempunyai nilai IKG tinggi 2 kali puncak dalam 2 kali siklus bulan. Hal tersebut dapat disimpulkan bahwa setiap bulan, teripang jenis Pisang mengalami fase pemijahan di alam, hal tersebut mendukung pernyataan Darsono (1999) bahwa teripang mengalami pemijahan sepanjang tahun. Hal tersebut sesuai dengan teori yang diungkapkan darsono (1995) bahwa sampai matang gonad, terjadi pada bulan April, September, dan November, dimana hal tersebut sesuai dengan waktu pelaksanaan penelitian yakni dilakukan pada bulan September, Oktober, hingga November. Tuwo (1999) dalam penelitiannya di Perairan Sulawesi Barat pada teripang Holothuria scabra dan Villalobos et al. (2013) dalam penelitiannya di Meksiko pada teripang jenis Holothuria fuscocinerea mempertegas bahwa teripang jenis tersebut juga mengalami pemijahan. Jenis teripang Gamet dan Pisang dalam penelitian ini mengalami puncak pemijahan pada bulan baru setiap bulannya.

Hasil pengamatan indeks kematangan gonad Teripang Gamet (Stichopus sp.) selama dua siklus bulanan, didapatkan bahwa nilai indeks tertinggi terjadi pada fase Bulan Baru. Nilai IKG pada fase bulan tersebut sebesar (13,25-15,65\%). Menurut Mustofa (2014) hal tersebut menandakan bahwa kondisi Teripang Gamet masuk kedalam fase pemijahan. Penelitian ini dilaksanakan pada bulan September-November, dimana terjadi fase pemijahan dari jenis Teripang Gamet. Hal ini sesuai dengan penelitian yang diungkapkan Sulardiono (2011) mengatakan bahwa terdapat kecenderungan Stichopus vastus untuk melakukan proses pemijahan pada sesudah bulan-bulan tersebut, atau pada Oktober - November (awal musim peralihan dari musim timur ke musim barat) 
dan Juni (akhir musim peralihan). Hal tersebut sesuai dengan penelitian (Purcell et al., 2012) bahwa spesies ini mengalami puncak pada bulan November dan tingkat kematangan gonad tertinggi terjadi pada fase bulan baru/new moon. Sehingga dapat ditarik kesimpulan bahwa teripang pulot mengalami puncak kematangan gonad pada bulan baru setiap bulannya.

\section{KESIMPULAN}

Teripang Pisang yang berada di Pulau Nyamuk mempunyai karakter morfometri panjang maksimal $23,30-23,68 \mathrm{~cm}$, lebar maksimal 4,53-4,65 cm dengan berat maksimal mencapai 310,65 gram. Sedangkan karakter morfometri Teripang Gamet yaitu mempunyai panjang maksimal mencapai 28,59-28,82 cm, lebar maksimal mencapai 7,97-8,13 cm, dengan berat tegumen maksimal mencapai 690,63 gram. Teripang Pisang dan Gamat melakukan pemijahan pada pada saat fase Bulan Baru pada setiap bulan, dimana nilai Indeks IKG lebih dari $10 \%$. Teripang Pisang dengan nilai IKG sebesar (12,58-14,94\%) dan Teripang Gamat dengan nilai IKG sebesar (13,25-15,65\%). Hasil tersebut dapat digunkaan sebagai rekomendasi waktu penangkapan, dimana nelayan dilarang untuk menangkap teripang pada saat bulan baru di Perairan Pulau Nyamuk, Karimunjawa

\section{DAFTAR PUSTAKA}

Brueggeman, P. 1998, Underwater Field Guide to Ross Island and McMurdo Sound, Antarctica. The National Science Foundation's Office of Polar Progams sponsored Norbert WU. University California, San Diego 268p.

Dakrory, A.I., Fahmy, S.R., Soliman, A.M., Mohamed, A.S. \& Amer, S.A, 2015, Protective and curative effects of the sea cucumber Holothuria atra extract against DMBA-induced hepatorenal diseases in rats. BioMed research international, 2015:563652 11 pages

Darsono, P. 1999, Perkembangan Pembenihan Teripang Pasir, Holothuria Scabra Jaegar, di Indonesia. Oseana XXIV(3):35-45.
Darsono, P. 2003, Teripang (Holothuroidea): Sumberdaya Teripang dan Pengolahannya. Oseana, XXXII(2):1-9.

Darsono, P. 2007. Teripang (Holothuroidea): Kekayaan alam dalam keragaman biota laut. Oseana, XXXII(2):1-10.

Effendie, M.I. 1979. Methods of Fisheries Biology. Yayasan Dewi Sri. Bogor. P. 36.

Elfidasari, D., Noriko, N., Wulandari, N. \& Perdana, A.T. 2012, Identifikasi jenis teripang genus Holothuria asal perairan sekitar Kepulauan Seribu berdasarkan perbedaan morfologi. Jurnal Al-azhar Indonesia seri sains dan teknologi, 1(3): 140-146.

Hadi, A., Hartati, R. \& Widianingsih, W, 2011, Fauna Echinodermata di Indonoor Wreck, Pulau Kemujan, Kepulauan Karimunjawa. IImu Kelautan: Indonesian Journal of Marine Sciences, 16(4):236-242.

Hartati R. \& Yanti, H. 2006, Kajian Gonad Teripang Getah (Holothuria vagabunda) pada Saat Bulan Penuh dan Bulan Baru di Perairan Bandengan, Jepara. IImu Kelautan : Indonesian Journal of Marine Sciences, $11(3): 126-132$.

Hartati, R., Widianingsih \& Pringgenies, D. 2009. Pembenihan dan Pembesaran Teripang Pasir (Holothuria scabra: Echinodermata). BP UNDIP, Semarang. halaman 128.

Hasan, M.H. 2019. Destruction of sea cucumber populations due to overfishing at Abu Ghosoun area, Red Sea. The Journal of Basic and Applied Zoology, 80 (1):1-10. doi: 10.1 186/s41936-019-0074-6.

Husain, G., Tamanampo, J.F.W.S. \& Manu, G.D. 2017, Community Structure of Sea Cucumber (Holothuroidea) In The Coastal Area Of The Island Of Jailolo Subdistrict Nyaregilaguramangofa South Halmahera Regency West of North Maluku. Jurnal Ilmiah Platax, 5(2):177-188.

James, D.B. 1996, Culture of sea-cucumber. CMFRI Bulletin-Artificial reefs and seafarming technologies, 48:120-126.

Kerr, A.M., Netchy, K. \& Gawel, A.M. 2006, Survey of the shallow-water sea cucumbers of the central Philippines. A Report to the Municipalities of Negros Oriental, Cebu and Bohol, local Bantay Dagat groups, Coastal Conservation and Education Foundation, Inc., and Silliman University-Angelo King Center for Research 
and Environmental Management. University of Guam Marine Laboratory. 56 halaman

Kohler, S., Gaudron, S.M. \& Conand, C, 2009, Reproductive biology of Actinopyga echinites and other sea cucumbers from La Reunion (Western Indian Ocean): Implications for fishery management. The Western Indian Ocean Journal of Marine Science. 8(1):97-111. doi: 10.4314/wiojms. v8il.56679.

Martoyo, J., Aji, N. \& Winanto, T. 2006. Budidaya Teripang (Edisi Revisi). Penerbit Penebar Swadaya, Jakarta. 75 halaman.

Mustagfirin \& Hartati, R. 2016. Keanekaragaman Sumber Daya Teripang Di Perairan Pulau Nyamuk, Kepulauan Karimunjawa. Prosiding: Seminar Tahunan Penelitian Perikanan dan Kelautan VI Universitas Diponegoro, Semarang 12 November 2016.

Mustagfirin, Wijayanti, D.P. \& Subagio, 2021. Reproductive activity and morphometric assessment of three commercial species of sea cucumber (Echinodermata) from Karimunjawa National Park, Indonesia. Biodiversitas. 22(8): 3333-341 doi : 10.13057/ biodiv/d220829.

Mustofa, A. 2014. Frekuensi Kematangan Gonad Teripang (Holothuroidea) Di Pantai Bandengan Kabupaten Jepara. Jurnal Disprotek 5(1):1 1-54.

Navarro, G.P., Sanz, S.G. \& Tuya, F. 2012. Reproductive biology of the sea cucumber Holothuria sanctori (Echinodermata: Holothuroidea). Scientia Marina, 76(4):743-752. doi: 10.3989/sci mar.03543.15B.

Nontji, A. 2002. Laut Nusantara, PT Djambatan. $367 \mathrm{Hal}$.

Nurwidodo, N., Rahardjanto, A., Husamah, H., Mas'odi, M.O. \& Hidayatullah, M.S., 2018. Buku Panduan Mudahnya Budidaya Teripang (Terintegrasi dengan Rumput Laut). Eprints Umm : Malang. 39 halaman

Pangkey, H., Lantu, S., Manuand, L. \& Mokolensang, J. 2012. Prospect of sea cucumber culture in Indonesia as potential food sources. Journal of Coastal Develpopment 15(2): 114-124.

Purcell, S.W., Gossuin, H., Agudo, N.S. 2009. Status and Management of the Sea Cucumber Fishery of La Grande Terre, New Caledonia. WorldFish Center Studies: Malaysia. 121 halaman.
Purcell, S.W., Hair, C.A. \& Mills, D.J. 2012. Sea cucumber culture, farming and sea ranching in the tropics: Progress, problems and opportunities. Aquaculture, 368:6881.

Rahantoknam, S.P.T. 2017. Maturity gonad sea cucumber Holothuria scabra under the month cycle. IOP Conference Series: Earth and Environmental Science, 89:012015. doi: 10.1088/1755-131 5/89/1/012015.

Setyastuti, A. 2014. Echinodermata, Holothuria atra, in an intertidal seagrass bed off the Bama beach, Baluran National Park, East Java, Indonesia. Jurnal IImu dan Teknologi Kelautan Tropis, 6(1):31-39

Sulardiono, B. 2011. Kematangan Gonad Teripang Komersial Stichopus Vastus (Holothuriidea: Stichopodidae) di Perairan Karimunjawa, Kabupaten Jepara, Jawa Tengah. Jurnal Saintek Perikanan, 7(1):24-31.

Sulardiono, B. 2016. Potensi Pemanfaatan Teripang (Holothurians) di Perairan Karimunjawa, Kabupaten Jepara, Provinsi Jawa. Buletin Oseanografi Marina 5(1): 6472.

Sulardiono, B. \& Hendrarto, B. 2014, Analisis densitas teripang (Holothurians) berdasarkan jenis tutupan karang di perairan Karimun Jawa, Jawa Tengah. Jurnal Saintek Perikanan 10(1):7-12.

Suryaningrum, T.D. 2008. Teripang: potensinya sebagai bahan nutraceutical dan teknologi pengolahannya. Squalen, 3(2): 63-69.

Tuwo, A. 1999. Reproductive cycle of the holothurian Holothuria scabra in Saugi Island, Spermonde archipelago, South West Sulawesi, Indonesia. Infofish International, 6(97):23-29.

Tuwo, A. \& Conand, C. 1992, Reproductive biology of the holothurian Holothuria forskali (Echinodermata). Journal of the Marine Biological Association of the United Kingdom, 72(4):745-758.

Villalobos, F., Avila-Poveda, O.H. \& GutiérrezMéndez, I.S. 2013, Reproductive biology of Holothuria fuscocinerea (Echinodermata: holothuroidea) from Oaxaca, Mexico. Sexuality and Early Development in Aquatic Organisms, 1 (1):13-24.

Wibowo, S.Y., Setiabudi, E., Erlina, M.D. \& Tazwir, 1997. Teknologi Penanganan Dan 
Pengelolaan Teripang (Holohuroidea). Instansi Penelitian Perikanan Laut Slipi. Balai Penelitian Perikanan Laut. Pusat Penelitian dan Pengembangan Perikanan. Jakarta, 37 hal.

YU, B.S., \& Jo, I.H, 1984, Interaction of sea cucumber saponins with multilamellar liposomes. Chemico-biological interactions, 52(2):185-202.

Yusron, E., 2001, Sumberdaya teripang holothuridae di Perairan Teluk Kotania, Seram Barat, Maluku Utara. BPOL-LIPI Jakarta. pp.129-133. 